\title{
Development and validation of a nomogram for predicting carbapenem-resistant organism infection and prognostic risk factors analysis in elderly hospitalized patients
}

Research

Keywords:

Posted Date: December 14th, 2020

DOl: https://doi.org/10.21203/rs.3.rs-36090/v2

License: (1) This work is licensed under a Creative Commons Attribution 4.0 International License. Read Full License 


\section{Abstract}

The authors have requested that this preprint be withdrawn due to author disagreement.

\section{Full Text}

The authors have withdrawn this preprint from Research Square. 